\title{
ADAPTATION MEASURES TO SEA-LEVEL RISE \& SUBSIDENCE FOR COASTAL STRUCTURES
}

Thomas E. White, PhD, PE, D.CE, US Army Corps of Engineers (Galveston, Texas), Thomas.E.White@usace.army.mil

Sea-Level Rise (SLR) (and often subsidence) are realities in coastal settings. Planning adaptive designs for this reality is prudent, safe, and cost effective.

\section{T-WALL ONLY CONSTRUCTION}

All new floodwalls will be T-walls. All existing I-walls are recommended to be removed and replaced with the much more stable T-walls. I-walls have experienced leaks and partial failures during hurricane surges.

TRADITIONAL DESIGN (NO PLAN TO ADAPT)

Figure 1 shows design to protect against Still-Water Level(SWL), waves, runup, and SLR, but no adaptability.

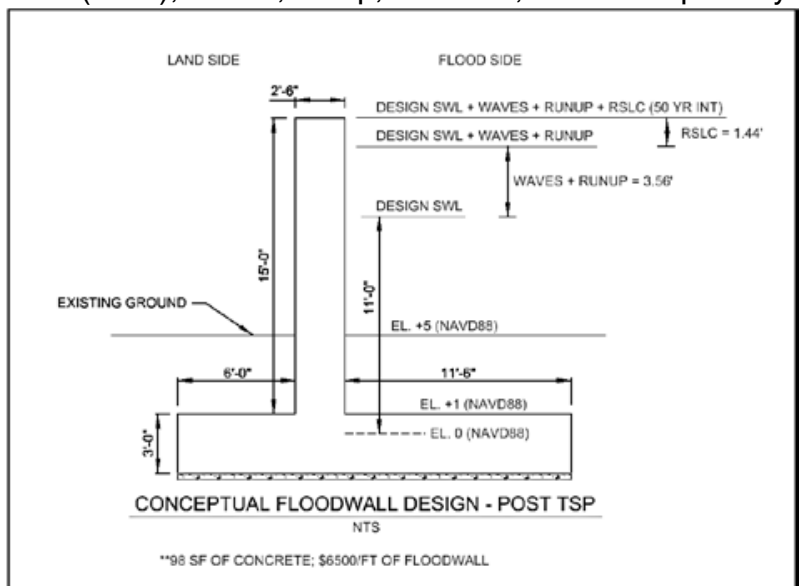

Figure 1 - Traditional Floodwall Construction, including SWL, waves, runup, and 50yr SLR, but no ability to adapt to faster (greater than 50yr Intermediate SLR) or longer times

PLANNED ADAPTABILITY TO FUTURE SLR

The additional foundation materials needed to allow for future unanticipated SLR will be included in all new construction. (Figure 2 shows the foundation is $5 \mathrm{ft}$ wider and $1 \mathrm{ft}$ deeper than in Figure 1.) This will prevent the wasteful practice of demolishing old walls in order to construct new higher ones, just because the need for higher walls was not initially anticipated.

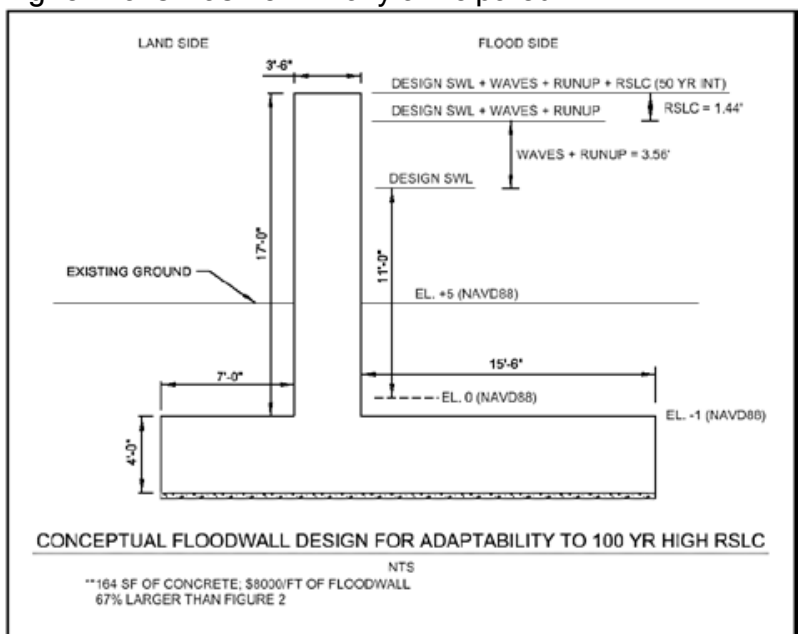

Figure 2 - All components from Figure 1 plus adaptability (wider and deeper footing)
Figure 3 below shows the $7 \mathrm{ft} 2$ in vertical extension to be added to the original wall that will be built in the Sabineto-Galveston project (Fig. 2). This specific height is the currently estimated $100 \mathrm{yr}$ SLR, but will be altered, based on actual measured SLR at the time of construction.

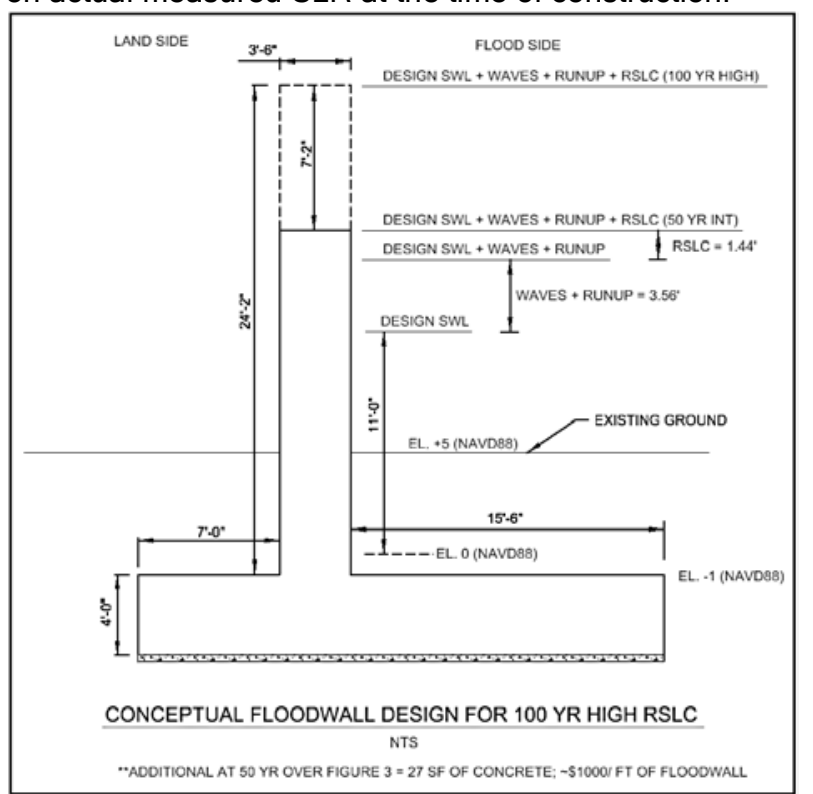

Figure 3 - Height raise for 100yr SLR

\section{COST}

Cost estimates are made to construct to current sea-level. Then additional costs are proposed to enable adaptation to SLR/subsidence. In our Texas flood-control projects, the extra $\$ 3,000$ is now always included in order to avoid the costly future possibility that adaptation will require demolition of the seawall. Costs below are cumulative.

Table 1: Sabine to Galveston Adaptation Costs -

Floodwall Costs for Different Options

\begin{tabular}{|l|l|}
\hline Floodwall Option & Cost per foot \\
\hline $\begin{array}{l}\text { Figure 1 - Intermediate SLRC at 50 } \\
\text { years, no Adaptability }\end{array}$ & $\$ 6,500$ \\
\hline $\begin{array}{l}\text { (not shown) Adapt and construct to } 50 \\
\text { year SLR }\end{array}$ & $\$ 3,000$ \\
\hline $\begin{array}{l}\text { Figure 2 - Enable future construction } \\
\text { to High RSLC at 100 years }\end{array}$ & $\$ 8,000$ \\
\hline $\begin{array}{l}\text { Figure 3 - Final raise to High SLRC at } \\
100 \text { years }\end{array}$ & $\$ 1,000$ \\
\hline
\end{tabular}

RATES OF SEA-LEVEL RISE \& SUBSIDENCE This paper concentrates on adaptability techniques, designs, and costs. On a related subject, a method for selecting a SLR Curve will be briefly discussed. Extremely accurate land-based gages measure local subsidence, which is decelerating. SLR is accelerating, but the future rate is very uncertain. This Texas Sabineto-Galveston project is unique in that it objectively selected which sea-level curve to use, based on BenefitCost ratios. (The SLRC with the highest Benefit/Cost ratio was the Intermediate curve. Low and High curves produced lower $\mathrm{B} / \mathrm{C}$ ratios.) 